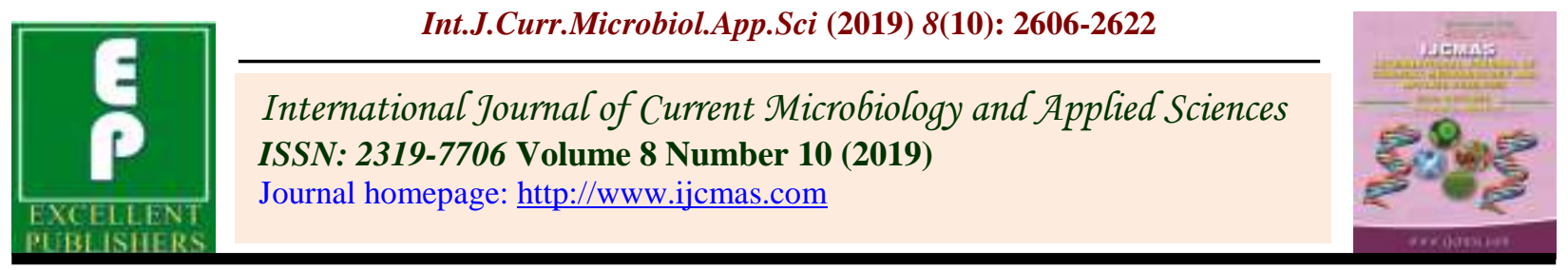

Original Research Article

https://doi.org/10.20546/ijcmas.2019.810.301

\title{
In-vitro Regeneration of Apple Cultivar (Malus domestica L. cv. Galmast)
}

\author{
Subzar Ahmad Rather* and Junaid Jalal \\ Department of Biotechnology, Mewar University, Gangarar, Chitttorgarh (Rajasthan), India \\ *Corresponding author
}

\section{Keywords}

In-vitro

regeneration,

shooting, rooting,

hardening,

acclimatization,

apple cv. Galmast

Article Info

Accepted:

25 September 2019

Available Online:

10 October 2019

\section{A B S T R A C T}

Double sterilized and pre-chilled shoot apices of Galmast cultivar obtained from mature trees (MTSTs) and in vitro raised seedlings (SBSTs) were inoculated on MS medium augmented with BA, Kn and TDZ with and without PG. Increase in BA concentration up to $5.0 \mu \mathrm{M}$ resulted in axillary shoot proliferation in about $40 \%$ shoots with a maximum of $14 \pm 0.72$ shoots per explant. SBSTs (seedling born shoot tips) of same cultivar developed light yellow loose callus (LYLC) when they were cultured on $\operatorname{MS}\left(x^{1 / 2}\right)$ medium fortified with $\mathrm{BA}(2.0-3.5 \mu \mathrm{M})$ and produced axillary and adventitious shoots when the same medium was supplemented with $\mathrm{BA}(4.0-5.0 \mu \mathrm{M}$. The best response was observed on $\mathrm{MS}(1 / 2)+\mathrm{BA}(4 \mu \mathrm{M})+\mathrm{PG}(10 \mu \mathrm{M})$ However, about $40 \%$ SBSTs showed axillary shoot proliferation on MS(1/2) + TDZ $(4 \mu \mathrm{M})+\mathrm{PG}(10 \mu \mathrm{M})$ and produced a maximum average number of $40 \pm 0.72$ shoots per subculture. However, $25-30 \%$ shoots showed axillary shoot proliferation (ASP) with further increase in the concentration of TDZ to 4.0, 4.5 and $5.0 \mu \mathrm{M}$ with PG $(10 \mu \mathrm{M})$. The number of shoots produced was $14 \pm 2.11,12 \pm 0.32$ and 14. \pm 0.45 . The shoots obtained through the mature tree explant culture (MTEC) and seedling born explant culture (SBEC) were sub cultured onto rooting medium containing auxins like IBA, IAA, NAA. Increase in its concentration to 2.0 and $2.5 \mu \mathrm{M}$ resulted in development of adventitious roots in about $60 \%$ plants obtained through MTEC with an average of $14 \pm 0.82$ roots per shoot. When the medium was fortified with $\operatorname{IBA}(2.0 \mu \mathrm{M})+$ $\mathrm{PG}(10 \mu \mathrm{M})$. When the concentration of IBA was increased further to $2.5 \mu \mathrm{M}$ the micro shoots produced adventitious roots (with cent per cent response) having an average number of $8 \pm 0.65$ roots per micro shoot. Further increase in the concentration of IBA to

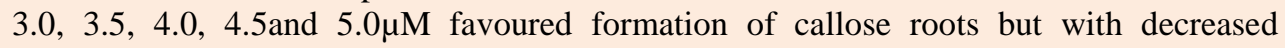
response. Best root initiation and elongation to obtain complete plantlets from the shoots derived from explants was observed on MS (1/2) supplemented with $\operatorname{IBA}(2.5 \mu \mathrm{M})+$ $\mathrm{PG}(10 \mu \mathrm{M})$.

\section{Introduction}

Propagation of woody plants by conventional methods necessarily limits the rate of output and makes the end product expensive. Tissue culture can overcome this problem since it has been reported that may acquire higher rooting capability after continuously subculturing in vitro (Hammatt \& Grant., 1993). Tissue culture techniques such as micropropagation provide a fast and dependable method for the production of a large quantity of uniform 
plantlets in a short time throughout the year (Zimmerman., 1981). Recently in apple, many reliable methods have been developed for both propagation of rootstocks and scions using in vitro techniques. Successful micropropagation of apple using microcuttings or single node cuttings is influenced by several internal and external factors, including genotype, physiological state of sampling, in vitro media constituents and their ratio, light, temperature and other factors(Dobranski et al., 2002). Apple (Malus $\times$ domestica Borkh.;Rosaceae) is an important fruit crop grown mainly in temperate regions of the world. In vitro tissue culture is a biotechnological technique that has been used to genetically improve cultivars (scions) and rootstocks. This updated review presents a synthesis of findings related to the tissue culture of apple and other Malus spp. between 2010 and 2018. Increasingly complex molecular studies that are examining the apple genome, for example, in a bid to identify the cause of epigenetic mutations and the role of transposable elements in this process would benefit from genetically stable source material, which can be produced in vitro. Several notable or curious in vitro culture methods have been reported to improve shoot regeneration and induce the production of tetraploids in apple cultivars and rootstocks. Existing studies have revealed the molecular mechanism underlying the inhibition of adventitious roots by cytokinin. The use of the plant growth correction factor allows hypothetical shoot production from leafderived thin cell layers relative to conventional leaf explants to be determined. This updated review will allow novices and established researchers to advance apple and Malus biotechnology and breeding programs. The tissue culture of domesticated apple (Malus $\times$ domesticaBorkh.) has a rich and extensive history spanning approximately 60 years (Dobránszki and Teixeira da Silva., 2015). Since the apple genome is highly heterozygous, a consistent genetic background in a given cultivar can be maintained only by vegetative propagation, i.e., cloning. This would be important in the production of genetically uniform scions and rootstocks for commercial apple production. In nurseries, apple plants are produced by grafting scions onto rootstocks. The rootstock determines some important traits of grafted trees, including growth vigour, yield and resistance or tolerance to biotic and abiotic stresses (Rom and Carlson.,1987; Laimer M.,, Barba M., 2011). The Cornell-Geneva (Geneva $^{\circledR}$ series) breeding program has bred several dwarf rootstocks that are resistant to diseases and pests and are also cold hardy. ${ }^{1}$ Several of these rootstocks have been extensively researched in recent years2,4-D 2,4dichlorophenoxyacetic acid, $2 i P$ 6- $(\gamma, \gamma-$ dimethylallylamino) purine, $A A$ ascorbic acid; $A B A$ abscisic acid, $A C$ activated charcoal, $A D$ apical dome, Alar-85daminozide, APM amiprophos methyl, $A S G V$ apple stem grooving virus, $A S P V$ apple stem pitting virus, B5 medium (Gamborg et al.,1968), $B A N^{6}$ benzyladenine (BA is used throughout even though BAP (6-benzylamino purine) may have been used in the original (Teixeira da Silva.,2012a), BAR $\quad \mathrm{N}^{6}$-benzyladenine riboside, $C A$ citric acid, $C H$ casein hydrolysate, $C I M$ callus induction medium; $d$ day(s), $D K W$ Driver and (Kuniyuki., 1984) medium, $G A_{3}$ gibberellic acid, IAA indole-3acetic acid, IBA indole-3-butyric acid; ISSR inter simple sequence repeat, Kin kinetin (6furfuryl aminopurine); $L P$ leaf primordium; mo month(s); MS(Murashige and Skoog., 1962) medium, mT meta-topolin (6-(3hydroxybenzylamino)purine) or $N^{6}$-metahydroxy-benzyladenine, $m T R$ metatopolinriboside or $N^{6}$-metahydroxy-benzyladenine ribozide, $N A A \alpha$-naphthalene-acetic acid, $N R$ not reported in the study, $P G$ phloroglucinol, $P G C F$ plant growth correction factor (Teixeira da Silva and Dobránszki., 2011, 2014), PGR plant growth regulator, $P G P R$ plant growthpromoting rhizobacteria, PICpicloram (4- 
amino-3,5,6-trichloro-pyridine-2-carboxylic acid), PP photoperiod, PP333paclobutrazol, $P P F D$ photosynthetic flux density, $P V P$ polyvinyl pyrrolidone, $Q L$ (Quoirin and Lepoivre) macroelements, Quoirin and (Lepoivre., 1977), RAPD random amplified polymorphic DNA; REM root elongation medium, RIM root induction medium, ROS reactive oxygen species, SEM shoot elongation medium, SIM shoot induction medium, $S M M$ shoot multiplication medium, $S N$ shoot number (or number of shoots), $S S R$ simple sequence repeat, TDZ thidiazuron $(N$ phenyl- $N$ '- 1,2,3-thiadiazol-5-ylurea), $t T C L$ transverse thin cell layer, $w$ week(s), WPM woody plant medium (Lloyd and McCown., 1980).

About 330 varieties of apple are known to have been under cultivation in Kashmir valley around 1972 but only a dozen are propagated at present on commercial scale. J \& K state has remained popular for its indigenous apple varieties.Galmast striped red and yellow, this New Zealand native was brought to the United States in the early 1970s. Crisp, juicy and very sweet, Gala is excellent for snacks or salads, and is also good for pies, sauce and baking. U.S. Galas are available nationwide yearround.

Gala apples bring a sweet, clean crunch to the table. This apple is one of the first apples of the season to ripen, brightening up green summer foliage with hues of red over yellow. Most Gala apple trees (like Starkrimson ${ }^{\circledR}$ Gala) produce small to medium fruit. For a larger piece of the "apple pie", choose the Stark ${ }^{\circledR}$ GrandGala ${ }^{\mathrm{TM}}$. These trees are excellent pollination companions for any Golden Delicious variety; and with both a Golden and a Gala growing in your yard, you'll be all set for some blue ribbon pies!This striped yellow and red apple is sweet and firm. Excellent for snacking and salads, Galmast is also a good for pies, baking and sauce making. U.S. Galmast are available nationwide year- round. The present study aims for developed of efficient plant regeneration protocol of apple (cv. Galmast) from shoot apices.

\section{Materials and Methods}

The present research work was carried out with the aim assessing morphogenetic and organogenetic potential of explants from mature trees and in vitro raised seedlings to develop complete protocol for mass propagation of apple cultivar i.e. Galmast

\section{Collection of Explants}

The source material was obtained from mature trees and in vitro born seedlings. The explants used from mature trees were obtained from different orchards at Zakura, Shopian and Pattan area in District Baramulla. The explants used as experimental material were $2-3 \mathrm{~cm}$ long sprouts which were cut by sterile razors and collected in polythene bags containing moist cotton to prevent wilting and were taken to laboratory. Explants were either processed for inoculations immediately or placed in a refrigerator overnight. In vitro born seedlings / shoots obtained after aseptic germination of mature apple seeds.

\section{Sterilization of Plant Material}

Shoot apices $(0.5 \mathrm{~cm}$ long), obtained from young and actively growing shoots of 40-50 year old mature trees were placed in enamel trays containing tap water with two to three drops of detergent (Labolene 5\%) and a drop Tween-20 (surfactant).

The explants were stirred gently and then washed with running tap water until all the traces of soap were completely removed. The explants were then placed in different sterilants for different time durations to attain complete asepsis and then rinsed 3 times with filtered water (obtained from water purifier) and finally with double distilled water. They 
were then kept in $10-25 \mu \mathrm{M}$ kinetin solution overnight (24hours) in refrigerator at $4^{\mathrm{O}} \mathrm{C}$ to reduce leaching of phenolic compounds. Next day further processes were carried under Laminar air flow cabinet.

Table.1 Composition of different media used for apple tissue culture

\begin{tabular}{|c|c|c|c|c|c|}
\hline \multirow[t]{3}{*}{ S.No } & \multirow[t]{2}{*}{ Medium } & WM & MSM & QM & WPM \\
\hline & & White (1943) & \begin{tabular}{|c} 
Murashige and \\
Skoog(1962)
\end{tabular} & Quoirin(1972) & $\begin{array}{l}\text { Lloyd and Mc. } \\
\text { Crown (1980) }\end{array}$ \\
\hline & $\begin{array}{c}\text { Concentration } \rightarrow \\
\text { Ingredients } \downarrow\end{array}$ & $\mathrm{mg} / \mathrm{L}$ & $\mathrm{mg} / \mathrm{L}$ & $\mathbf{m M}$ & $\mathrm{mg} / \mathrm{L}$ \\
\hline A & Macronutrients & & & & \\
\hline 01 & $\mathrm{NH}_{4} \mathrm{NO}_{3}$ & - & 1650 & 5.0 & 400 \\
\hline 02 & $\mathrm{KNO}_{3}$ & 80 & 1900 & 17.8 & - \\
\hline 03 & $\mathrm{CaCl}_{2} \cdot 2 \mathrm{H}_{2} \mathrm{O}$ & - & 440 & - & 96 \\
\hline 04 & $\mathrm{MgSO}_{4} \cdot 7 \mathrm{H}_{2} \mathrm{O}$ & 750 & 370 & 1.5 & 370 \\
\hline 05 & $\mathrm{~K}_{2} \mathrm{SO}_{4}$ & - & - & - & 990 \\
\hline 06 & $\mathrm{KH}_{2} \mathrm{PO}_{4}$ & - & 170 & 2.0 & 170 \\
\hline 07 & $\left(\mathrm{NH}_{4}\right)_{2} \mathrm{SO}_{4}$ & - & - & - & 556 \\
\hline 08 & $\mathrm{Ca}\left(\mathrm{NO}_{3}\right)_{2} \cdot 4 \mathrm{H}_{2} \mathrm{O}$ & 300 & - & 5.1 & - \\
\hline 09 & $\mathrm{Na}_{2} \mathrm{SO}_{4}$ & 200 & - & - & - \\
\hline 10 & $\mathrm{NaH}_{2} \mathrm{PO}_{4} \cdot \mathrm{H}_{2} \mathrm{O}$ & 19 & - & - & - \\
\hline B & Micronutrients & & & & \\
\hline 01 & $\mathrm{KI}$ & 0.75 & 0.83 & 0.1 & - \\
\hline 02 & $\mathrm{KCl}$ & 65 & - & & \\
\hline 03 & $\mathrm{H}_{3} \mathrm{BO}_{3}$ & 1.5 & 6.2 & 0.1 & 6.2 \\
\hline 04 & $\mathrm{MnSO}_{4} \cdot \mathrm{H}_{2} \mathrm{O}$ & 5.0 & 22.3 & 0.1 & 22.3 \\
\hline 05 & $\mathrm{MnSO}_{4} \cdot 4 \mathrm{H}_{2} \mathrm{O}$ & - & - & - & 0.1 \\
\hline 06 & $\mathrm{ZnSO}_{4} .7 \mathrm{H}_{2} \mathrm{O}$ & 3.0 & 8.6 & 0.03 & 8.6 \\
\hline 07 & $\mathrm{CuSO}_{4} \cdot 5 \mathrm{H}_{2} \mathrm{O}$ & 0.01 & 0.025 & 0.0001 & 0.25 \\
\hline 08 & $\mathrm{Fe}_{2}\left(\mathrm{SO}_{4}\right)_{3}$ & 2.5 & - & - & - \\
\hline 09 & $\mathrm{MoO}_{3}$ & 0.001 & - & - & - \\
\hline 10 & $\mathrm{CoCl}_{2} \cdot 6 \mathrm{H}_{2} \mathrm{O}$ & - & 0.025 & 0.0001 & - \\
\hline 11 & $\mathrm{Na}_{2} \mathrm{MoO}_{4} \cdot 2 \mathrm{H}_{2} \mathrm{O}$ & - & 0.25 & 0.001 & 0.25 \\
\hline 12 & $\mathrm{Fe}_{2}\left(\mathrm{SO}_{4}\right)_{3} \cdot 7 \mathrm{H}_{2} \mathrm{O}$ & - & 27.8 & 0.1 & 27.8 \\
\hline 13 & $\mathrm{Na}_{2}$ EDTA. $2 \mathrm{H}_{2} \mathrm{O}$ & - & 37.3 & 0.1 & 37.3 \\
\hline $\mathrm{C}$ & Organics & & & & \\
\hline 01 & Thiamine $\mathrm{HCl}$ & 0.01 & 0.1 & 0.0012 & 0.25 \\
\hline 02 & Nicotinic acid & 0.01 & 0.5 & 0.0041 & - \\
\hline 03 & PyridoxinHCl & 0.01 & 0.5 & 0.0024 & - \\
\hline 04 & Glycine & 3.0 & 2.0 & - & 0.5 \\
\hline 05 & Myo-inositol & - & 100 & 0.56 & 100 \\
\hline 06 & Sucrose & $2.0 \%$ & $3.0 \%$ & $2.0 \%$ & $2.0 \%$ \\
\hline 07 & Agar & $0.8 \%$ & $0.8 \%$ & $0.8 \%$ & $0.8 \%$ \\
\hline
\end{tabular}


Table.2 Stock solutions of the different constituents of MS (1962) medium

\begin{tabular}{|c|c|c|c|c|}
\hline \multicolumn{3}{|c|}{ Stock Solution Code (MSSS-01) } & \multicolumn{2}{|c|}{ Major Salts [strength =10X] } \\
\hline Constituents & $\begin{array}{l}\text { Quantity } \\
(\mathrm{mg} / \mathrm{L}) \text { in } \\
\text { original } \\
\text { medium }\end{array}$ & $\begin{array}{c}\text { Quantity } \\
\text { dissolved in } \\
\text { stock solution }\end{array}$ & $\begin{array}{c}\text { Final volume } \\
\text { of the stock } \\
\text { solution }\end{array}$ & $\begin{array}{l}\text { Qua. to be used } \\
\text { for preparation } \\
\text { of one Litre MS } \\
\text { Medium }\end{array}$ \\
\hline $\mathrm{NH}_{4} \mathrm{NO}_{3}$ & 1650 & $16.5 \mathrm{~g}$ & \multirow{5}{*}{$1000 \mathrm{ml}$} & \multirow{5}{*}{$100 \mathrm{ml}$} \\
\hline $\mathrm{KNO}_{3}$ & 1900 & $19.0 \mathrm{~g}$ & & \\
\hline $\mathrm{CaCl}_{2} \cdot 2 \mathrm{H}_{2} \mathrm{O}$ & 440 & $04.4 \mathrm{~g}$ & & \\
\hline $\mathrm{MgSO}_{4} \cdot 7 \mathrm{H}_{2} \mathrm{O}$ & 370 & $03.7 \mathrm{~g}$ & & \\
\hline $\mathrm{KH}_{2} \mathrm{PO}_{4}$ & 170 & $01.7 \mathrm{~g}$ & & \\
\hline \multicolumn{2}{|c|}{ Stock Solution Code (MSSS-02) } & & \multicolumn{2}{|c|}{ Minor Salts [strength =100X] } \\
\hline $\mathrm{KI}$ & 0.83 & $08.3 \mathrm{~g}$ & \multirow{7}{*}{$500 \mathrm{ml}$} & \multirow{7}{*}{$5.0 \mathrm{ml}$} \\
\hline $\mathrm{H}_{2} \mathrm{BO}_{3}$ & 6.20 & $62.0 \mathrm{~g}$ & & \\
\hline $\mathrm{MnSO}_{4} \cdot 4 \mathrm{H}_{2} \mathrm{O}$ & 22.30 & $2230 \mathrm{~g}$ & & \\
\hline $\mathrm{ZnSO}_{4} \cdot 7 \mathrm{H}_{2} \mathrm{O}$ & 8.60 & $8.60 \mathrm{~g}$ & & \\
\hline $\mathrm{Na}_{2} \mathrm{MoO}_{4} \cdot 2 \mathrm{H}_{2} \mathrm{O}$ & 0.250 & $0.25 \mathrm{~g}$ & & \\
\hline $\mathrm{CuSO}_{4} .5 \mathrm{H}_{2} \mathrm{O}$ & 0.025 & $0.025 \mathrm{~g}$ & & \\
\hline $\mathrm{CoCl}_{2} \cdot 6 \mathrm{H}_{2} \mathrm{O}$ & 0.025 & $0.025 \mathrm{~g}$ & & \\
\hline \multicolumn{2}{|c|}{ Stock Solution Code (MSSS-03) } & & \multicolumn{2}{|c|}{ Iron Source [strength $=100 \mathrm{X}$ ] } \\
\hline $\mathrm{FeSO}_{4} \cdot 7 \mathrm{H}_{2} \mathrm{O}$ & 27.8 & $2.78 \mathrm{~g}$ & \multirow{2}{*}{$500 \mathrm{ml}$} & \multirow{2}{*}{$5.0 \mathrm{ml}$} \\
\hline $\mathrm{Na}_{2}$ EDTA. $2 \mathrm{H}_{2} \mathrm{O}$ & 37.3 & $3.73 \mathrm{~g}$ & & \\
\hline \multicolumn{2}{|c|}{ Stock Solution Code (MSSS-04) } & \multicolumn{3}{|c|}{ Myo-Inostol [strength =50X] } \\
\hline Myo-inositol & 100 & $5.0 \mathrm{~g}$ & $250 \mathrm{ml}$ & $5.0 \mathrm{ml}$ \\
\hline \multicolumn{2}{|c|}{ Stock Solution Code (MSSS-05) } & \multicolumn{3}{|c|}{ Organic ingredients $[$ strength $=100 \mathrm{X}]$} \\
\hline Thiamine $\mathrm{HCl}\left(\mathrm{B}_{1}\right)$ & 0.1 & $10.0 \mathrm{mg}$ & \multirow{4}{*}{$500 \mathrm{ml}$} & \multirow{4}{*}{$5.0 \mathrm{ml}$} \\
\hline Nicotinic acid $\left(\mathrm{B}_{5}\right)$ & 0.5 & $50.0 \mathrm{mg}$ & & \\
\hline Pyridoxine $\mathrm{HCl}\left(\mathrm{B}_{6}\right)$ & 0.5 & $50.0 \mathrm{mg}$ & & \\
\hline Glycine & 2.0 & $200.0 \mathrm{mg}$ & & \\
\hline
\end{tabular}

\section{Selection of Nutrient Media}

Four nutrient formulations namely (White's., 1943) medium, (Murashige and Skoog's (MS)
(1962) medium, (Quoirin et al., 1977) but the explants responded well on MS medium. Thus all trials were later on carried on MS (1962) medium. However, use of full strength salt formulations with media supplements yielded 
poor results to the reduced salt strength i.e. half salt strength. The medium was supplemented with different auxins (2,4-D, IAA, NAA and IBA), cytokinins (BA and $\mathrm{Kn}$ ), gibberellin (GA3) and $P G$ and TDZ in different concentrations and combinations and encouraging results were yielded.

\section{Preparation of Stock Solutions}

Weighing of all constituents of a nutrient medium individually and their mixing was made to the highest level of accuracy. Concentrated stock solutions of major salts, minor salts, myoinositol, iron source, vitamins and phytohormones were prepared on need basis which not only saved time but was more accurate. The stock solutions were kept in dark glass bottles and stored in refrigerators. The strength and composition of stock solutions is depicted in Table 2.

\section{Preparation of Nutrient Medium}

For all trials the medium was prepared in sterile vials of Borosil glass. Required quantities from (pre-prepared) stock solutions of MS major and minor salts, vitamins and myo-inositol were mixed together for one litre basal medium. This was followed by the addition of phytohormones from their stock solutions as per the need. (Table 5). Double distilled water was added to increase the volume of the solution. Sucrose (3\%) was added and allowed to get dissolved properly. $\mathrm{pH}$ of the solution was adjusted between 5.25.8 by adding $\mathrm{NaOH}(0.1 \mathrm{~N})$ or $\mathrm{HCl}(0.1 \mathrm{~N})$ drop by drop. Final volume of the medium was adjusted, by adding more double distilled water, before the medium was gelled with 0.8 $\%$ agar. The medium was finally dispensed in different culture vials which were then tightly plugged with sterilized cotton. It was then autoclaved at 15-20 pounds/inch pressure at $121{ }^{\circ} \mathrm{C}$ for 20 minutes and then allowed to cool.

\section{Inoculation}

Sterilized explants were inoculated onto aseptic basal medium (control) and phytohormone supplemented medium on the hood of Laminar air flow chamber. The culture vials were then placed in incubation room under cool fluorescent illumination.

\section{Subculture}

Subculture was carried out on the hood of Laminar air flow chamber under aseptic conditions after every 4-6 weeks depending upon the organogenetic and proliferation potential of the explants. The products of explants were carefully separated out and inoculated in separate vials.

\section{Regular Observation and Data Recording}

The cultures were daily monitored for contamination and growth. The changes in explant were recorded on weekly basis and the data was put in proper sequence and in tabulated form. It was also transcribed at the end of every week and stored as e-content.

\section{Data Analysis and Interpretation}

After recording correct and accurate data about nature of media used, phytohormonal concentration, date of inoculation, incubation and subculture, nature of light i.e., its intensity, quality and duration, humidity etc. and their impact on explant response, callus growth, organogenesis, embryogenesis, it was analysed through statistical and mathematical methods. Ten / twenty replicates were taken for each treatment and observations were recorded at the end of every week. Analysis of variance (ANOVA) was carried to determine the significance of the results using Dunkan's multiple range test $(a \leq 0.05)$ for mean number of shoots/ roots produced. 


\section{Hardening}

The plantlets obtained from different explants through repeated subcultures were finally left in culture vials with open mouth for three days in the incubation room, transferred to thumb pots containing peat-vermiculite or soil-peat mixture and then taken out of incubation room of the lab. Attempts were made to acclimatize plants under laboratory conditions as the green house facility could not be availed due to its late installation in the campus.

\section{Results and Discussion}

\section{Culture Establishment and shoot multiplication}

Double sterilized and pre-chilled shoot apices of Galmast cultivar obtained from mature trees (MTSTs) and in vitro raised seedlings (SBSTs) were inoculated on MS medium augmented with BA, Kn and TDZ with and without PG the results of which are summarised in tables 3 and 4 . As in case of Red fuji and Golden Delicious cultivars, little response was seen on MS medium with full strength of its salts but good results were recorded when the strength of the medium was reduced to half.

\section{Impact of BA alone}

Under the influence of $\mathrm{BA}(0.5-1.5 \mu \mathrm{M})$ the MTSTs (mature tree shoot tips) turned brown within 48 hours and then faced necrosis. Increase in BA concentration upto $3.5 \mu \mathrm{M}$ resulted in the formation of light yellow callus (LYC) at cut ends in about 35\% shoo tips. Further increase in its concentration upto $5.0 \mu \mathrm{M}$ resulted in axillary shoot proliferation in about $40 \%$ shoots with a maximum of $14 \pm 0.72$ shoots per explant (Table 3 ).

SBSTs (seedling born shoot tips) of same cultivar developed light yellow loose callus
(LYLC) when they were cultured on $\operatorname{MS}\left(x^{1 / 2}\right)$ medium fortified with $\mathrm{BA}(2.0-3.5 \mu \mathrm{M})$ and produced axillary and adventitious shoots when the same medium was supplemented with $\mathrm{BA}(4.0-5.0 \mu \mathrm{M})$. However, only a maximum of $70 \%$ cultures developed multiple shoots with maximum average number of $24 \pm 0.72$ shoots per shoot per subculture (Table 4).

\section{Impact of BA with PG}

Culture of MTSTs on MS(1/2) supplemented with BA and PG yielded good results (PlateA, Figs.01 and 02). No response was seen when they were cultured under the influence of low cytokinin i.e. $\mathrm{BA}(0.5-2.0 \mu \mathrm{M})+$ $\mathrm{PG}(10 \mu \mathrm{M})$. Increase in $\mathrm{BA}$ concentration from 2.0 to $3.5 \mu \mathrm{M}$ resulted in the development of callus at cut ends in $25 \%$ shoots. Further increase in BA concentration from 4.0 to $5.0 \mu \mathrm{M}$ with $\mathrm{PG}(10 \mu \mathrm{M})$ favoured growth of apical bud as well as axillary buds and their proliferation (ASP). The best response was observed on $\mathrm{MS}(1 / 2)+\mathrm{BA}(4 \mu \mathrm{M})+$ $\mathrm{PG}(10 \mu \mathrm{M})$ (Plate-B, Figs.03). Unlike Red fuji and Golden Delicious cultivars increase in BA concentration from 4.0 to 4.5 and $5.0 \mu \mathrm{M}$ decreased percentage of response from $90 \%$ to $70 \%$ and number of adventitious and axillary shoots from $42 \pm 0.71$ to $36 . \pm 0.82$ per shoot as depicted in table 3 . The shoots obtained were subcultured individually or in lumps several times to increase number of shoots (Plate-B, Figs.04 and 05 and Plate-A, Fig.01). The potential of shoot proliferation continued in the subcultures attempted. SBSTs of same cultivar developed light yellow loose callus (LYLC) when the medium was fortified with $\mathrm{BA}(2.0-3.5 \mu \mathrm{M})+\mathrm{PG}(10 \mu \mathrm{M})$ but developed axillary and adventitious shoots when the medium was supplemented with BA(4.0$5.0 \mu \mathrm{M})+\mathrm{PG}(10 \mu \mathrm{M})$ (Plate-A, Figs.01) . Best (cent percent) response was seen on the medium containing $\mathrm{BA}(4.0 \mu \mathrm{M})$ when a maximum average number of $50 \pm 1.35$ shoots 
were produced per shoot per subculture (PlateB, Figs. 02 and 03) (Table 4). The potential of shoot proliferation increased in the subcultures attempted. Similar findings were reported by (Kouider et al., 1986), whose work focused on micropropagation of quince. They showed that the rate of multiplication increases with the increase in the amount of BAP, while, the rate of elongation decreases. (Gladyshava., 1987) in trying to multiply the papaw tree in vitro, showed that the amount of BAP is positively correlated at the rate of multiplication.

\section{Impact of TDZ alone}

Use of TDZ did not yield successful results in case of MTSTs and only a maximum of $30 \%$ shoots produced loose creamy callus (LCC) at cut ends (CCE). However, about 40\% SBSTs showed axillary shoot proliferation on $\mathrm{MS}(1 / 2)+\mathrm{TDZ}(4 \mu \mathrm{M})+\mathrm{PG}(10 \mu \mathrm{M})$ and produced a maximum average number of $40 \pm 0.72$ shoots per subculture (Table 3 ).

\section{Impact of TDZ with PG}

Addition of PG to the medium containing TDZ did not help in getting successful results during the culture of MTSTs as no response was seen while using $0.52 .5 \mu \mathrm{M}$ TDZ with $\mathrm{PG}(10 \mu \mathrm{M})$. Loose creamy callus (LCC) at cut ends (CCE) was observed when concentration of TDZ was increased to 3.0 and $3.5 \mu \mathrm{M}$ with $\mathrm{PG}(10 \mu \mathrm{M})$. However, $25-30 \%$ shoots showed axillary shoot proliferation (ASP) with further increase in the concentration of TDZ to 4.0, 4.5 and $5.0 \mu \mathrm{M}$ with $\mathrm{PG}(10 \mu \mathrm{M})$. The number of shoots produced was $14 \pm 2.11,12 \pm 0.32$ and $14 . \pm 0.45$ respectively (Table 3 ).

When SBSTs of same cultivar were cultured under the influence of TDZ+PG callus formation was observed under low concentrations of TDZ $(3.0$ and $3.5 \mu \mathrm{M})$ and axillary shoot proliferation was seen in $45 \%$ shoots (Table 4).

Previous studies on apple reveals that explants from in vitro raised seedlings have higher organogenetic potential when compared with those obtained from mature trees. Present findings run parallel to it whereby seedling based explants have shown three times greater organogenetic potential than adult tree based explants. This is, however, of little practical importance as plants raised from seedlings in field never yield fruits unless they are subjected to grafting. While working on shoot tips of different apple cultivars most researchers have reported shoot proliferation and direct multiple shoot formation under the influence of BA (1.0-5.0 $\mu \mathrm{M}$ ) alone (Ciccotti et al., 2008; Bahmani, et al., 2016). In present work direct shoot multiplication in the shoot tips from mature trees was achieved when the medium was fortified with BA $(4.0-5.0 \mu \mathrm{M})$ alone, $\mathrm{BA}(4.0-5.0 \mu \mathrm{M})+\mathrm{PG}(10 \mu \mathrm{M})$ and TDZ $(4.0-5.0 \mu \mathrm{M})+\mathrm{PG}(10 \mu \mathrm{M})$ but best results were observed only under the influence of $\mathrm{BA}(4 \cdot 0-5.0 \mu \mathrm{M})+\mathrm{PG}(10 \mu \mathrm{M})$.

Thus results achieved on the culture of shoot apices run parallel to the findings of (James and Thurbon., 1981 : Zimmerman and Broome., 1981 and Modgil et al., 1994) but contradicts with the findings of other researchers. Some researchers like (Sharma $e t$ al., 2004 : Nabeela et al., 2009) have succeeded in inducing direct shoot multiplication in the shoot apices of some apple cultivars under the influence of TDZ and have reported BA to be less effective in comparison to TDZ. On the other hand, (Welander., 1988) have reported direct shoot multiplication when the medium was augmented with PG alone. In contrast to these findings, (Modgil et al., 1994) have achieved great success the same by using BA (15.0 $\mu \mathrm{M}$ ) with PG.

\section{Rooting of in vitro raised Shoots}

The shoots obtained through the mature tree explant culture (MTEC) and seedling born explant culture (SBEC) were subcultured onto 
rooting medium containing auxins like IBA, IAA, NAA as summarised in (tables 4 and 5).

\section{Impact of IBA without PG}

Use of 1.0 and $1.5 \mu \mathrm{M}$ IBA alone promoted callus formation at basal end in about $5 \%$ shoots. The callus produced was creamy yellow (CYC). Increase in its concentration to 2.0 and $2.5 \mu \mathrm{M}$ resulted in development of adventitious roots in about $60 \%$ plants obtained through MTEC with an average of $14 \pm 0.82$ roots per shoot (Table 4 ).

The shoots obtained through SBEC also showed similar response. About $85 \%$ shoots produced adventitious roots with an average of $12 \pm 0.82$ roots per shoot when the medium was fortified with $\operatorname{IBA}(2.5 \mu \mathrm{M})$.

\section{Impact of IBA with PG}

Whereas callose roots were produced when the concentration of IBA was increased to $2.0 \mu \mathrm{M}$. Further increase in the concentration of IBA to $2.5 \mu \mathrm{M}$ resulted in the initiation and development of adventitious roots in all shoots (table 5) (100\% response) with an average of $12 \pm 0.81$ roots per shoot (Plate-A, Fig.02; Plate-A, Fig.03; Plate-C- Fig.03).

Microshoots of Galmast apple cultivar obtained through SBEC cultured under the influence of IBA $(0.5,1.0$ and $1.5 \mu \mathrm{M})$ with $\mathrm{PG}(10 \mu \mathrm{M})$ did not show any response and produced callose roots when the medium was fortified with $\operatorname{IBA}(2.0 \mu \mathrm{M})+\mathrm{PG}(10 \mu \mathrm{M})$. When the concentration of IBA was increased further to $2.5 \mu \mathrm{M}$ the microshoots produced adventitious roots (with cent percent response) having an average number of $8 \pm 0.65$ roots per microshoot. (Plate-A, Figs.04 and 05; Plate-A, Fig.06; Plate-A, Fig.03; Plate-C, Fig.05). Further increase in the concentration of IBA to $3.0,3.5,4.0,4.5$ and $5.0 \mu \mathrm{M}$ favoured formation of callose roots but with decreased response.

\section{Impact of IAA, NAA and IBA+IAA+NAA}

When the microshoots obtained through MTEC were cultured under the influence of IAA or NAA no response was seen until their concentration was increased to $3.0 \mu \mathrm{M}$ while callus formation was observed at cut ends (CCE) of microshoots at $3.0-5.0 \mu \mathrm{M}$ concentration in about $30 \%$ shoots. The callus produced was creamy yellow and loose (CYC). Rooting could not be achieved with the help of IAA and NAA alone or with BA (Table 4 and 5).

\section{Impact of IBA + IAA + NAA}

When shoot apices of the same selected cultivar obtained through MTSTC and SBSTC were cultured on $\mathrm{MS}\left(\times^{1 / 2}\right)$ supplemented with IBA + IAA NAA (2.0-5.0 $\mu \mathrm{M})$, they produced callus at cut ends (CCE). The callus produced by the shoots obtained through MTEC was loose light brown massive callus (LLMC) while that produced by those obtained through SBEC was loose and light yellow (LYLC) (Tables 4 and 5).

Best root initiation and elongation to obtain complete plantlets from the shoots derived from explants was observed on MS (1/2) supplemented with IBA $(2.5 \mu \mathrm{M})+\mathrm{PG}(10 \mu \mathrm{M})$ which corroborates with the results of (Zimmerman et al., 1989) has reported use of PG with IBA for root initiation. (Pawalicki.,1992) and (Puentae., 1992) reported strong inhibition of rooting in microshoots by BA. They also reported that splitting of shoot segments enhanced rooting on suitable media. BA has been found to show strong inhibition in rooting of shoots when applied alone. Present work has also found BA to show strong inhibition in rooting. In combination with low auxin (BA $5 \mu \mathrm{M}+$ IBA $2.5 \mu \mathrm{M})$ normal but delayed rooting was observed. It is probably because of low endogenous cytokinin level in the shoots. 
Fig. 01 Establishment of shoot tips on MS $\left(\times^{1 / 2}\right)+\mathrm{BA}(4.0 \mu \mathrm{M})+\mathrm{PG}(10 \mu \mathrm{M})$

Five weeks after inoculation

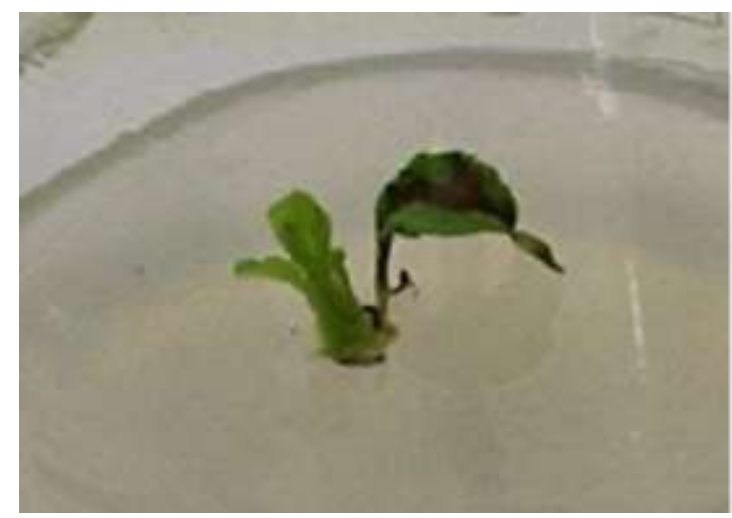

Fig. 03 Further shoot multiplication of subcultured shoots on $\operatorname{MS}\left(x^{1 / 2}\right)+\mathrm{BA}(4.0 \mu \mathrm{M})+\mathrm{PG}(10 \mu \mathrm{M})$

14 weeks after culture period

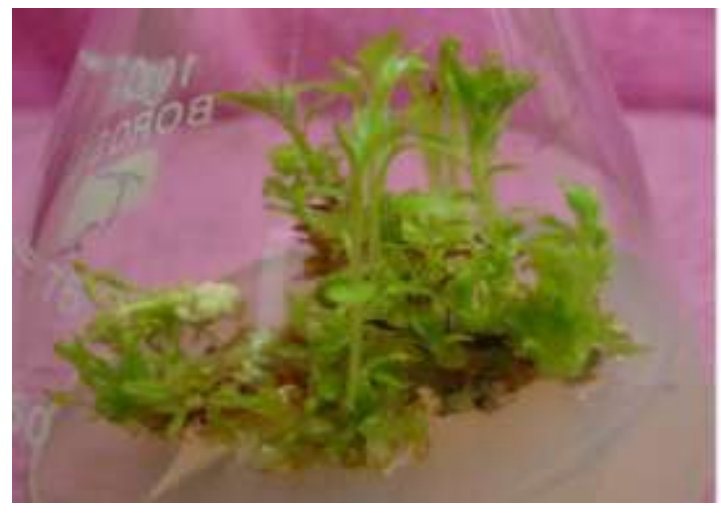

Fig. 05 Subcultured shoot on rooting medium $\operatorname{MS}\left(\times^{1 / 2}\right)+\mathrm{BA}(2.5 \mu \mathrm{M})+\mathrm{PG}(10 \mu \mathrm{M})$

After one week of subculture

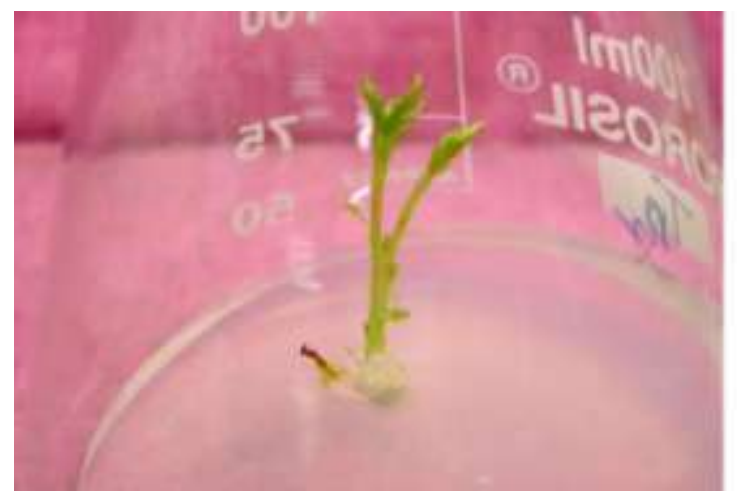

Fig. 02 Shoot multiplication on $\operatorname{MS}(\times 1 / 2)+B A(4.0 \mu \mathrm{M})+\mathrm{PG}(10 \mu \mathrm{M})$ After eight weeks of culture period

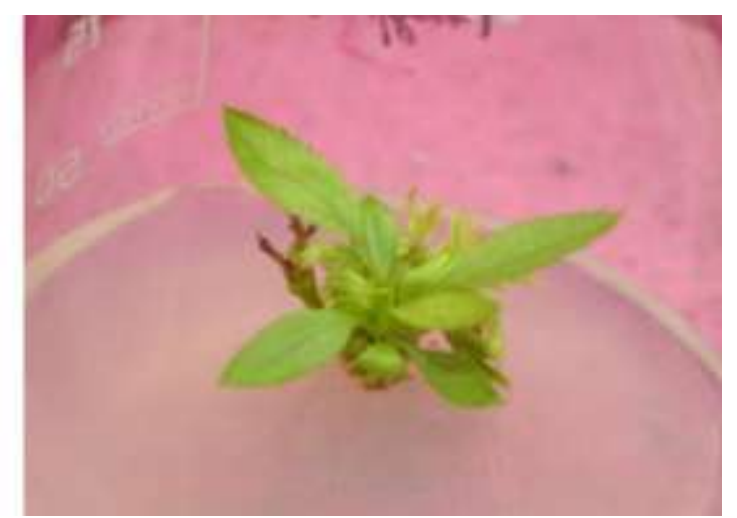

Fig. 04 Subcultured shoots showing further proliferation and multiplication on $\mathrm{MS}(\times 1 / 2)+\mathrm{BA}(4.0 \mu \mathrm{M})+\mathrm{PG}(10 \mu \mathrm{M})$ After eighth subculture

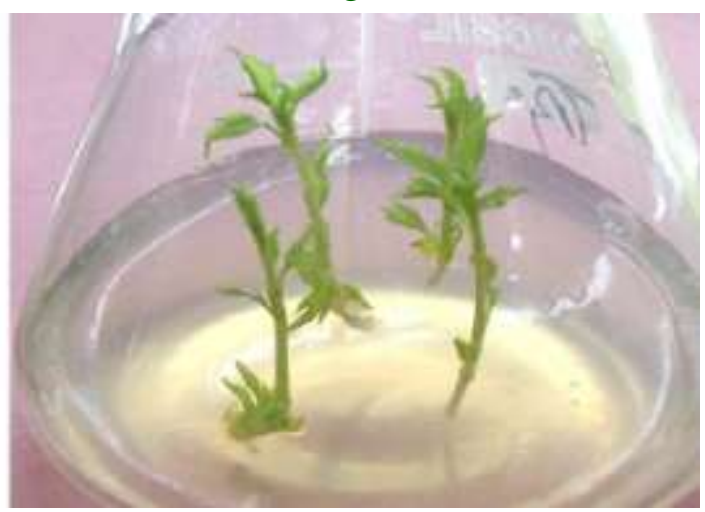

Fig. 06 Normal rooting of subcultued shoot on $\operatorname{MS}\left(\times^{1 / 2}\right)+\operatorname{IBA}(2.5 \mu \mathrm{M})+\mathrm{PG}(10 \mu \mathrm{M})$ After three weeks of subculture

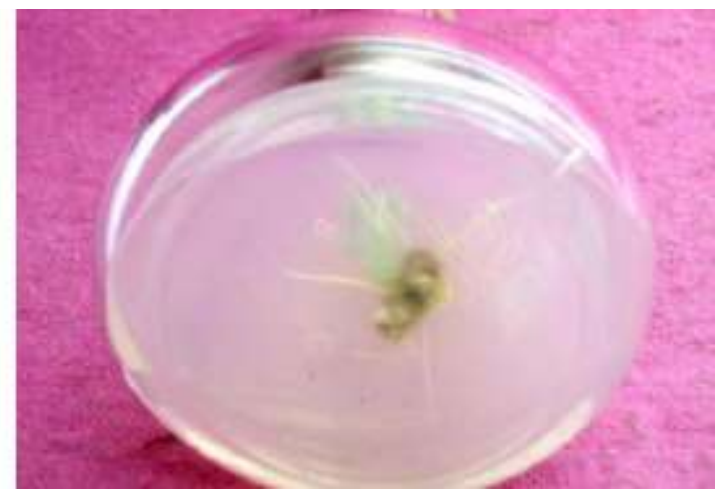

PLATE - A 


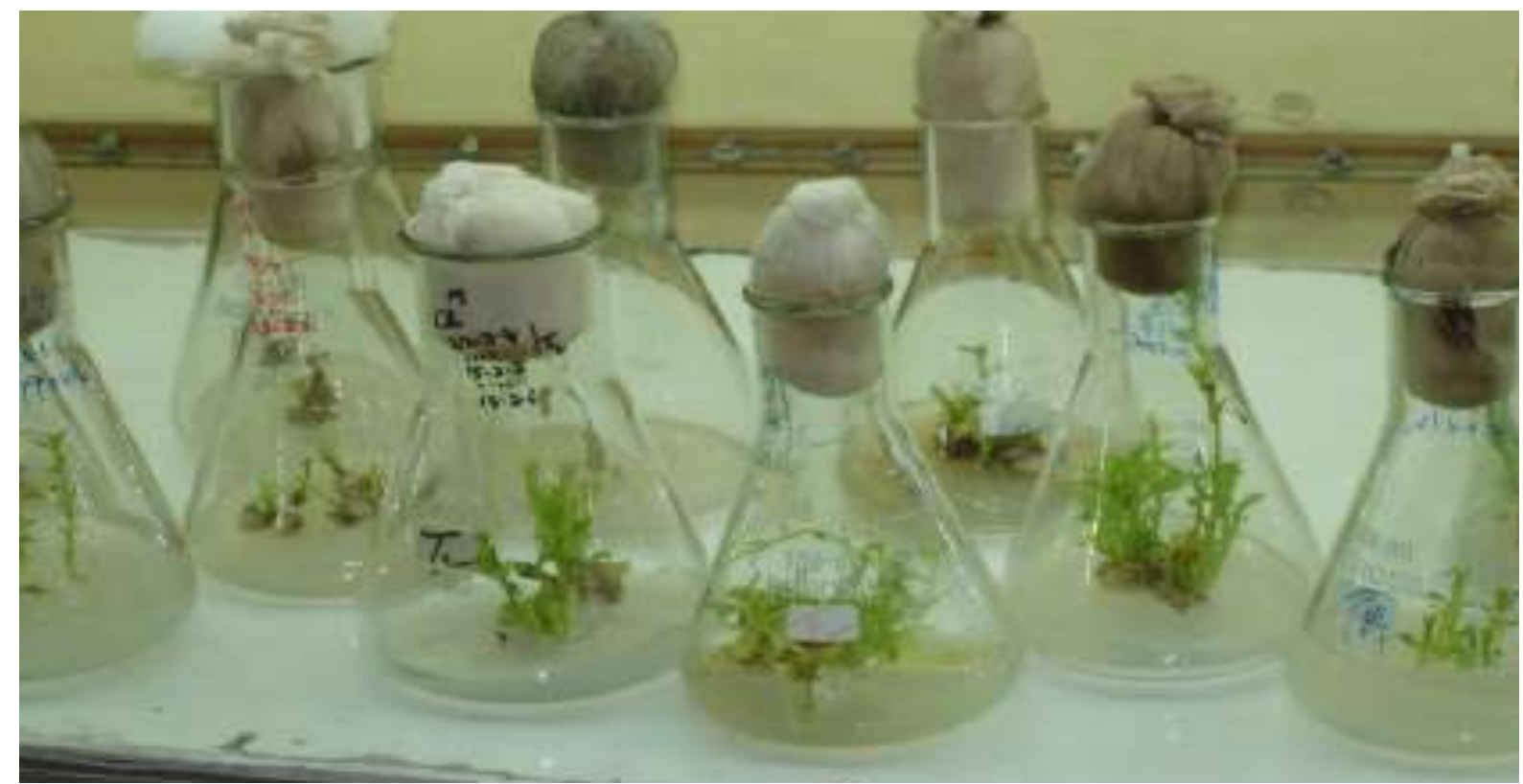

Fig.1 Multiplication of subcultured shoots on $\mathrm{MS}\left(\times^{1 / 2}\right)+\mathrm{BA}(5 \mu \mathrm{M})+\mathrm{PG}(10 \mu \mathrm{M})$ after 16 months of culture period

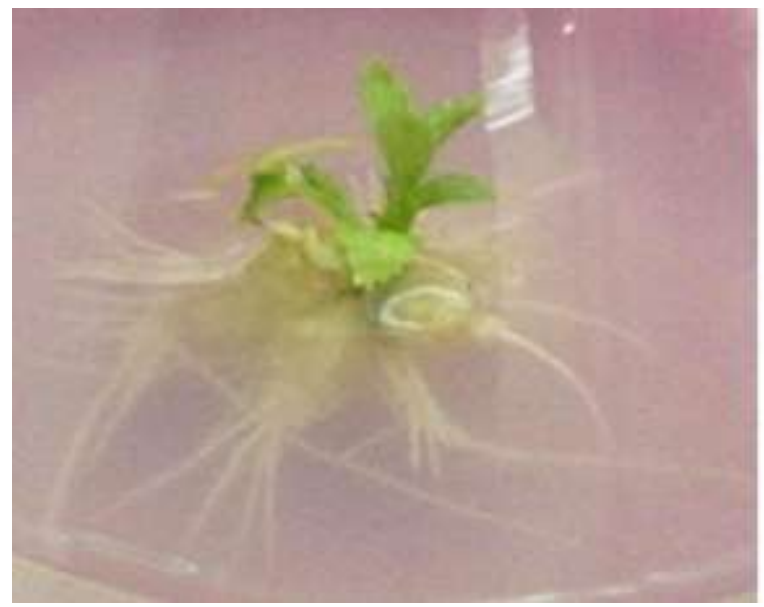

Fig.2 Rooting of sub cultured shoots on $\operatorname{MS}\left(\times^{1 / 2}\right)+\mathrm{BA}(4 \mu \mathrm{M})+\mathrm{PG}(10 \mu \mathrm{M})$. After 16 months of culture period

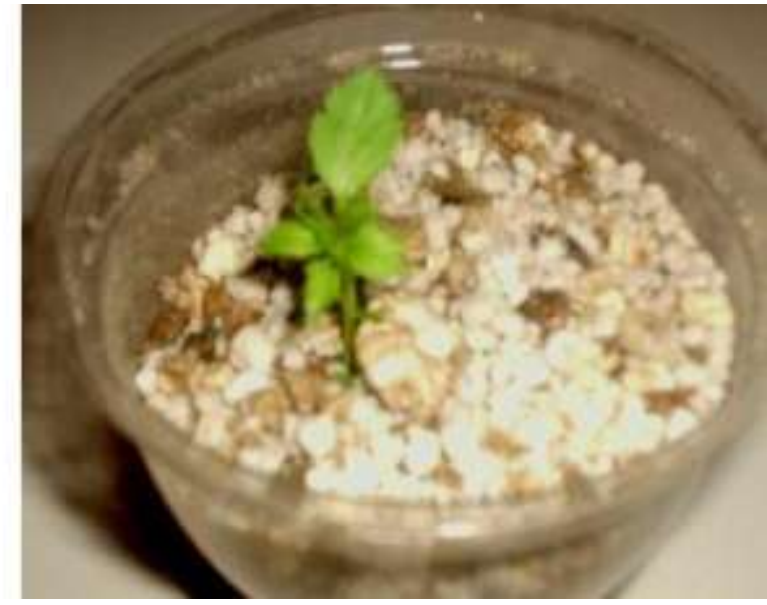

Fig.3 Micro plant in a thumb pot containing soil-peat Mixture

PLATE - B 
Fig.1 Establishment of shoot tips on $\operatorname{MS}(\times 1 / 2)+B A(4 \mu \mathrm{M})+\mathrm{PG}(10 \mu \mathrm{M})$

Three days after inoculation

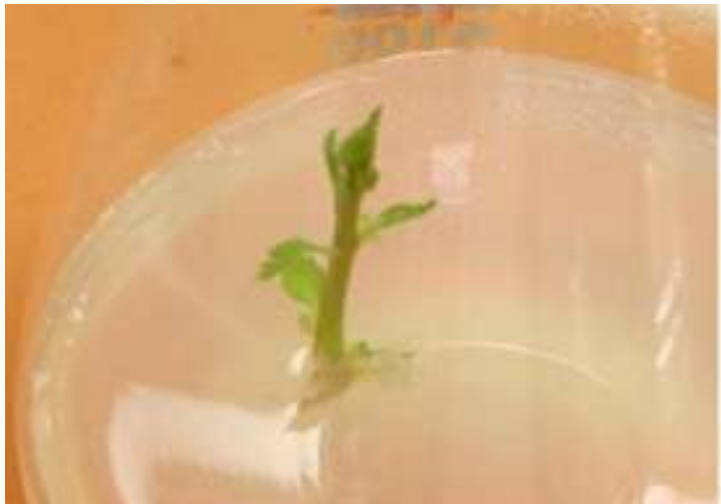

Fig. 03 Subculture for further shoot multiplication on MS

$(\times 1 / 2)+B A(4 \mu \mathrm{M})+\mathrm{PG}(10 \mu \mathrm{M})$

Eight weeks after culture period

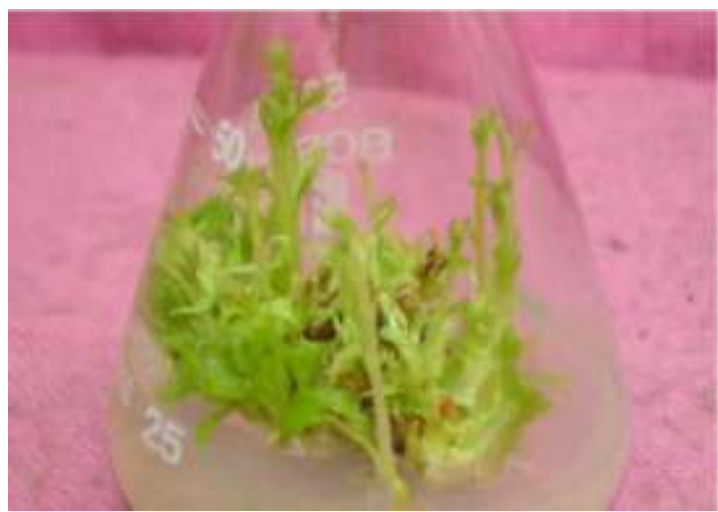

Fig. 05 Normal rooting of subcultured shoots on MS $\left(\times^{1 / 2}\right)+\operatorname{IBA}(2.5 \mu \mathrm{M})+\mathrm{PG}(10 \mu \mathrm{M})$ After two weeks of subculture

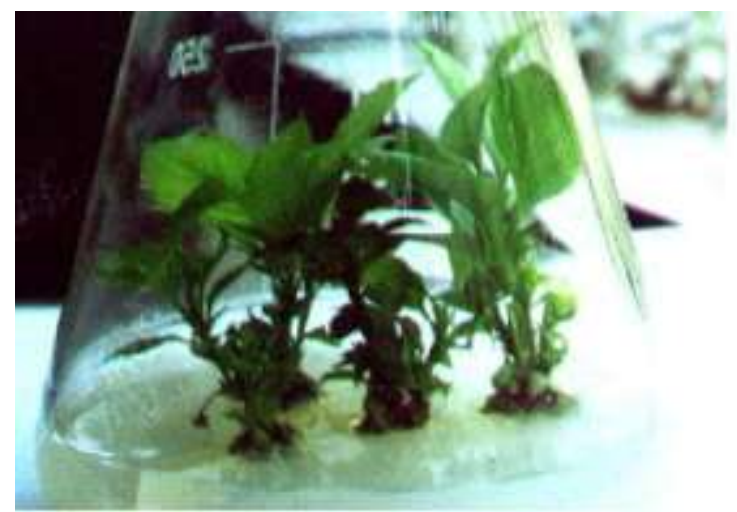

Fig. 02 Shoot multiplication on $\operatorname{MS}\left(\times \frac{1}{2}\right)+B A(4 \mu \mathrm{M})+\mathrm{PG}(10 \mu \mathrm{M})$

Four weeks of culture period

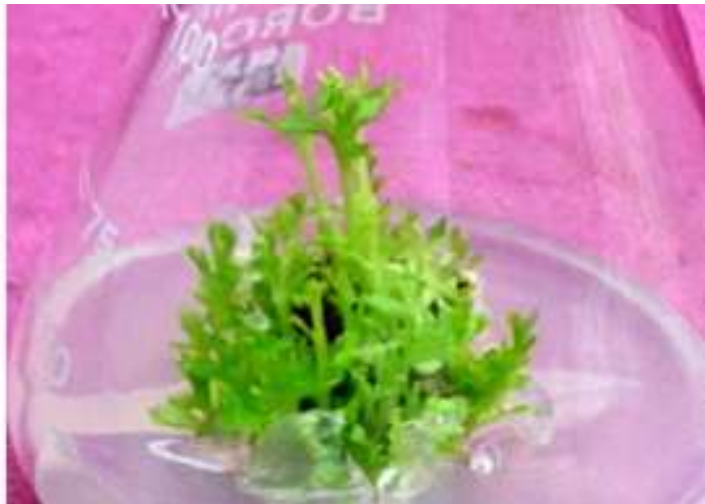

Fig. 04 Subculture of individual shoots for rooting on $\mathrm{MS}\left(\times^{1 / 2}\right)+\mathrm{IBA}(2.5 \mu \mathrm{M})+\mathrm{PG}$

$(10 \mu \mathrm{M})$ after sixth subculture

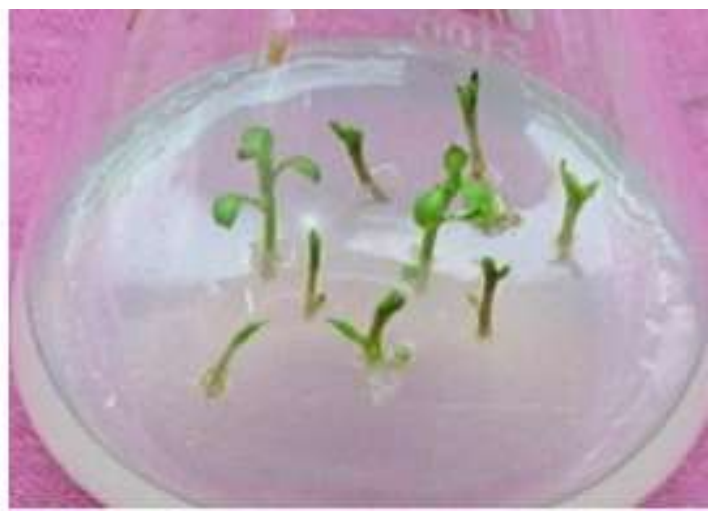

Fig. 06 Complete plantlets thus obtained in thumbpots containing soil-peat (1:1) mixture for hardening.

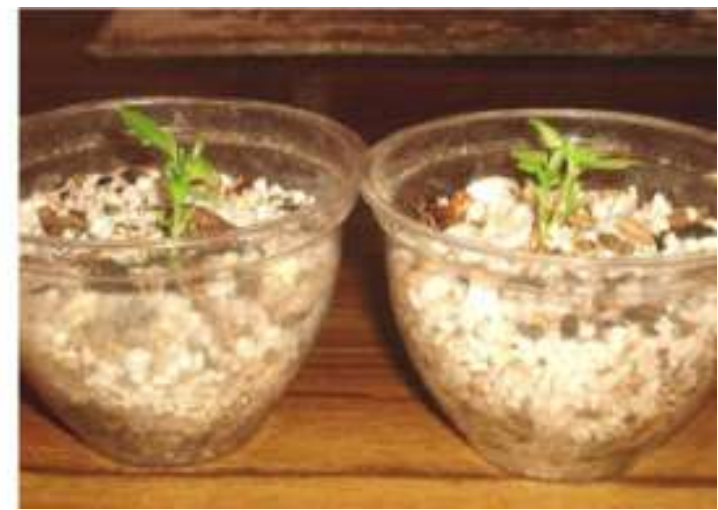

PLATE - C 
Table.3 Impact of cytokinins (BA and TDZ)* on the shoot apices from mature trees of Galmast cultivar of apple cultured in vitro on MS (half-strength) nutrient medium

\begin{tabular}{|c|c|c|c|c|}
\hline S.No & Phytohormones $(\mu \mathrm{M})$ & $\begin{array}{c}\text { Nature of Response } \\
\text { CH }\end{array}$ & $\begin{array}{c}\text { \% of response } \\
\text { CH }\end{array}$ & $\begin{array}{l}\text { Shoot Number Mean } \pm \mathrm{SD}^{* * /} \\
\text { Nature of callus CH }\end{array}$ \\
\hline 01 & CONTROL & $\mathrm{NR}$ & 0 & NA \\
\hline 02 & $\mathrm{BA}(0.5)$ & NR & 0 & $\mathrm{NA}$ \\
\hline 03 & BA (1.0) & NR & 0 & $\mathrm{NA}$ \\
\hline 04 & BA (1.5) & NR & 0 & NA \\
\hline 05 & $\mathrm{BA}(2.0)$ & $\mathrm{CCE}$ & 5 & LYC \\
\hline 06 & BA (2.5) & CCE & 5 & LYC \\
\hline 07 & BA (3.0) & CCE & 10 & LYC \\
\hline 08 & BA (3.5) & CCE & 20 & LYC \\
\hline 09 & BA (4.0) & ASP & 30 & $12 \pm 0.82$ \\
\hline 10 & BA (4.5) & ASP & 35 & $13 \pm 0.72$ \\
\hline 11 & $\mathrm{BA}(5.0)$ & ASP & 40 & $14 \pm 0.72$ \\
\hline 12 & $\mathrm{BA}(0.5)+\mathrm{PG}(10)$ & NR & 0 & NA \\
\hline 13 & $\mathrm{BA}(1.0)+\mathrm{PG}(10)$ & NR & 0 & $\mathrm{NA}$ \\
\hline 14 & $\mathrm{BA}(1.5)+\mathrm{PG}(10)$ & NR & 0 & NA \\
\hline 15 & $\mathrm{BA}(2.0)+\mathrm{PG}(10)$ & NR & 0 & NA \\
\hline 16 & $\mathrm{BA}(2.5)+\mathrm{PG}(10)$ & $\mathrm{CCE}$ & 20 & LYC \\
\hline 17 & $\mathrm{BA}(3.0)+\mathrm{PG}(10)$ & CCE & 25 & LYC \\
\hline 18 & $\mathrm{BA}(3.5)+\mathrm{PG}(10)$ & $\mathrm{CCE}$ & 20 & LYC \\
\hline 19 & $\mathrm{BA}(4.0)+\mathrm{PG}(10)$ & ASP & 90 & $42 \pm 0.71$ \\
\hline 20 & $\mathrm{BA}(4.5)+\mathrm{PG}(10)$ & ASP & 75 & $40 \pm 0.72$ \\
\hline 21 & $\mathrm{BA}(5.0)+\mathrm{PG}(10)$ & ASP & 70 & $36 \pm 0.82$ \\
\hline 22 & $\operatorname{TDZ}(0.5)$ & NR & 0 & NA \\
\hline 23 & TDZ (1.0) & NR & 0 & NA \\
\hline 24 & TDZ (1.5) & NR & 0 & $\mathrm{NA}$ \\
\hline 25 & TDZ (2.0) & $\mathrm{CCE}$ & 15 & LCC \\
\hline 26 & TDZ (2.5) & $\mathrm{CCE}$ & 15 & LCC \\
\hline 27 & TDZ (3.0) & $\mathrm{CCE}$ & 20 & LCC \\
\hline 28 & TDZ (3.5) & $\mathrm{CCE}$ & 15 & LCC \\
\hline 29 & TDZ (4.0) & $\mathrm{CCE}$ & 30 & LCC \\
\hline 30 & TDZ (4.5) & $\mathrm{CCE}$ & 30 & LCC \\
\hline 31 & TDZ (5.0) & CCE & 25 & LCC \\
\hline 32 & TDZ $(0.5)+$ PG (10) & NR & 0 & NA \\
\hline 33 & TDZ (1.0) + PG (10) & NR & 0 & NA \\
\hline 34 & TDZ (1.5) + PG (10) & NR & 0 & NA \\
\hline 35 & TDZ (2.0) + PG (10) & NR & 0 & NA \\
\hline 36 & TDZ (2.5) + PG (10) & NR & 0 & NA \\
\hline 37 & TDZ (3.0) + PG (10) & $\mathrm{CCE}$ & 15 & LCC \\
\hline 38 & TDZ (3.5) + PG (10) & CCE & 15 & LCC \\
\hline 39 & TDZ (4.0) + PG (10) & $\mathrm{CCE}$ & 15 & LCC \\
\hline 40 & TDZ (4.5) + PG (10) & ASP & 25 & $14 \pm 2.11$ \\
\hline 41 & TDZ (5.0) + PG (10) & ASP & 30 & $12 \pm 0.32$ \\
\hline \multicolumn{5}{|c|}{$\begin{array}{l}\text { CH - Galmast, CCE - Callus at Cut End; LYC-Loose Yellowish brown Callus; LCC-Loose Creamy Callus; NR - No } \\
\text { Response ASP - Adventitious Shoot Proliferation; NA- Not Applicable; } * \text { - Kinetin was also initially used but no } \\
\text { response was observed; Mean } \pm \text { SD**- Twenty replicates/ treatment. The highlighted values denote significant trials at the } \\
\text { level } \alpha \leq 0.05 \text {. }\end{array}$} \\
\hline
\end{tabular}


Table.4 In vitro response of subcultured shoots (obtained from mature trees) of Galmast cultivar of apple to auxins for rooting on MS(half strength nutrient medium

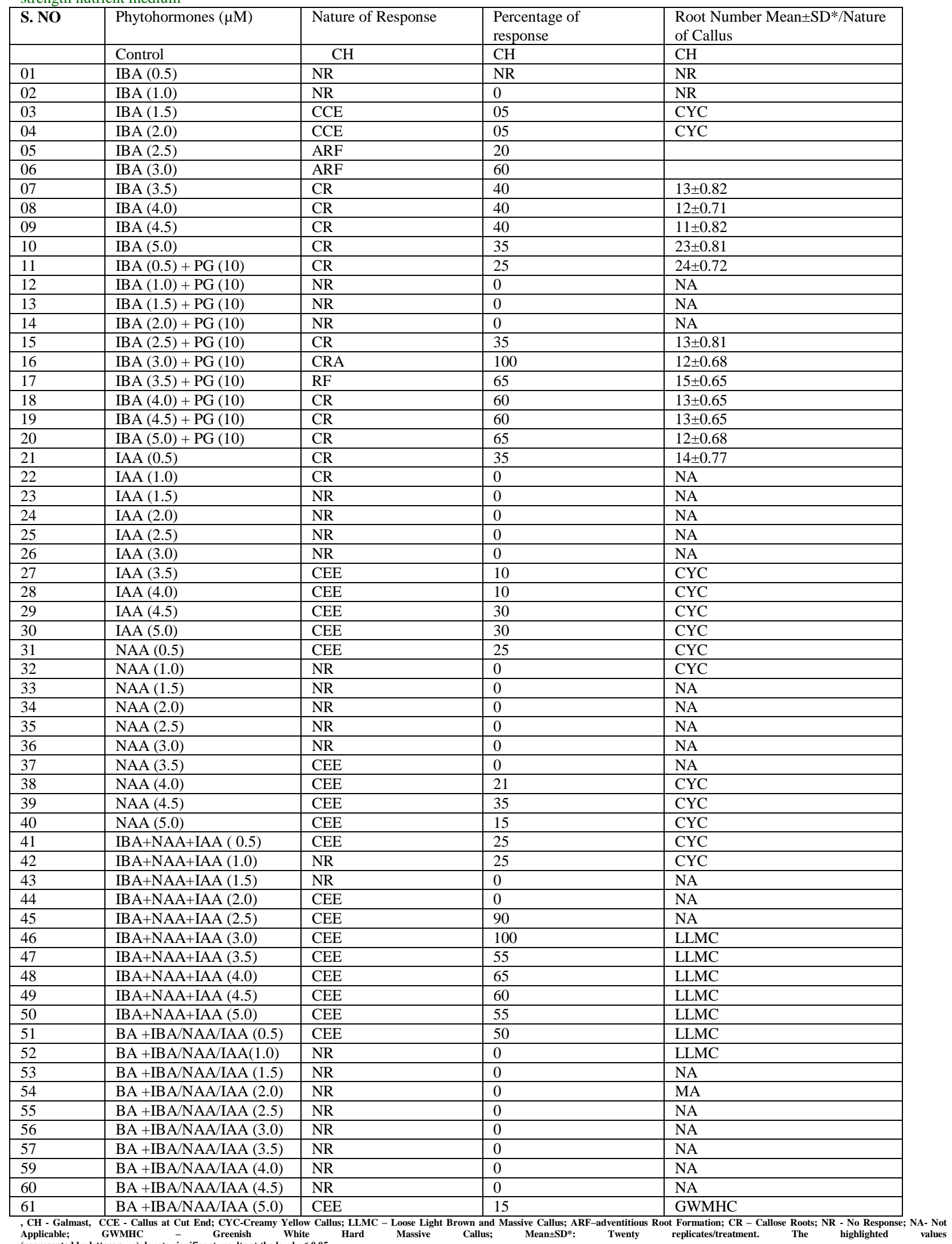


Table.5 Impact of cytokinins (BA and TDZ)* on the shoot apices from mature trees and in vitro grown seedlings of Galmast cultivar of apple cultured in vitro on MS (half-strength) nutrient medium

\begin{tabular}{|c|c|c|c|c|}
\hline S. No & Phytohormones $(\mu \mathrm{M})$ & $\begin{array}{l}\text { Nature of } \\
\text { Response }\end{array}$ & $\begin{array}{l}\text { Percentage of } \\
\text { response }\end{array}$ & $\begin{array}{l}\text { Shoot Number Mean } \pm \mathrm{SD}^{* *} / \\
\text { Nature of Callus }\end{array}$ \\
\hline 1 & Control & NR & 0 & NR \\
\hline 2 & IBA $(0.5)$ & NR & 0 & NA \\
\hline 3 & IBA (1.0) & CCE & 5 & CWLC \\
\hline 4 & IBA (1.5) & $\mathrm{CCE}$ & 10 & CWLC \\
\hline 5 & IBA (2.0) & ARF & 20 & $08 \pm 0.72$ \\
\hline 6 & IBA (2.5) & ARF & 85 & $10 \pm 0.68$ \\
\hline 7 & IBA (3.0) & $\mathrm{CR}$ & 35 & $10 \pm 0.88$ \\
\hline 8 & IBA (3.5) & $\mathrm{CR}$ & 15 & $12 \pm 0.64$ \\
\hline 9 & IBA (4.0) & $\mathrm{CR}$ & 15 & $10 \pm 0.70$ \\
\hline 10 & IBA (4.5) & $\mathrm{CR}$ & 10 & $14 \pm 0.82$ \\
\hline 11 & $\operatorname{IBA}(5.0)$ & $\mathrm{CR}$ & 10 & $23 \pm 0.82$ \\
\hline 12 & $\mathrm{IBA}(0.5)+\mathrm{PG}(10)$ & NR & 0 & NA \\
\hline 13 & $\mathrm{IBA}(1.0)+\mathrm{PG}(10)$ & NR & 0 & NA \\
\hline 14 & $\mathrm{IBA}(1.5)+\mathrm{PG}(10)$ & NR & 0 & NA \\
\hline 15 & $\mathrm{IBA}(2.0)+\mathrm{PG}(10)$ & $\mathrm{CR}$ & 35 & $11 \pm 0.65$ \\
\hline 16 & $\mathrm{IBA}(2.5)+\mathrm{PG}(10)$ & ARF & 70 & $8 \pm 0.70$ \\
\hline 17 & IBA (3.0) + PG (10) & $\mathrm{CR}$ & 70 & $10 \pm 0.78$ \\
\hline 18 & $\mathrm{IBA}(3.5)+\mathrm{PG}(10)$ & $\mathrm{CR}$ & 65 & $15 \pm 0.82$ \\
\hline 19 & $\mathrm{IBA}(4.0)+\mathrm{PG}(10)$ & $\mathrm{CR}$ & 65 & $16 \pm 0.82$ \\
\hline 20 & IBA (4.5) + PG (10) & $\mathrm{CR}$ & 50 & $16 \pm 0.71$ \\
\hline 21 & IBA (5.0) + PG (10) & $\mathrm{CR}$ & 0 & $16 \pm 0.77$ \\
\hline 22 & IAA $(0.5)$ & NR & 0 & NA \\
\hline 23 & IAA (1.0) & NR & 0 & NA \\
\hline 24 & IAA (1.5) & NR & 0 & NA \\
\hline 25 & IAA (2.0) & NR & 0 & NA \\
\hline 26 & IAA (2.5) & NR & 0 & NA \\
\hline 27 & IAA (3.0) & NR & 0 & NA \\
\hline 28 & IAA (3.5) & NR & 30 & NA \\
\hline 29 & IAA (4.0) & $\mathrm{CCE}$ & 30 & CWLC \\
\hline 30 & IAA (4.5) & $\mathrm{CCE}$ & 30 & CWLC \\
\hline 31 & IAA (5.0) & CCE & 0 & CWLC \\
\hline 32 & NAA $(0.5)$ & NR & 0 & NA \\
\hline 33 & NAA (1.0) & NR & 0 & NA \\
\hline 34 & NAA (1.5) & NR & 0 & NA \\
\hline 35 & NAA (2.0) & NR & 0 & NA \\
\hline 36 & NAA (2.5) & NR & 10 & NA \\
\hline 37 & NAA (3.0) & $\mathrm{CCE}$ & 10 & CWLC \\
\hline 38 & NAA (3.5) & $\mathrm{CCE}$ & 35 & CWLC \\
\hline 39 & NAA (4.0) & $\mathrm{CCE}$ & 15 & CWLC \\
\hline 40 & NAA (4.5) & $\mathrm{CCE}$ & 25 & CWLC \\
\hline 41 & NAA (5.0) & $\mathrm{CCE}$ & 0 & CWLC \\
\hline 42 & $\mathrm{IBA}+\mathrm{NAA}+\mathrm{IAA}(0.5)$ & NR & 0 & NA \\
\hline 43 & IBA+NAA+IAA (1.0) & NR & 0 & NA \\
\hline 44 & IBA+NAA+IAA (1.5) & NR & 75 & NA \\
\hline 45 & IBA+NAA+IAA (2.0) & CCE & 100 & LYLC \\
\hline 46 & IBA+NAA+IAA (2.5) & CCE & 50 & LYLC \\
\hline 47 & IBA+NAA+IAA (3.0) & $\mathrm{CCE}$ & 60 & LYLC \\
\hline 48 & IBA+NAA+IAA (3.5) & $\mathrm{CCE}$ & 65 & LYLC \\
\hline 49 & IBA+NAA+IAA (4.0) & $\mathrm{CCE}$ & 25 & LYLC \\
\hline 50 & IBA+NAA+IAA (4.5) & $\mathrm{CCE}$ & 55 & LYLC \\
\hline 51 & IBA+NAA+IAA (5.0) & $\mathrm{CCE}$ & 50 & LYLC \\
\hline
\end{tabular}

CH- Gala mast, CCE - Callus at Cut End; CWLC-Creamy White Loose Callus; LYLC - Light Yellow Loose Callus; ARF-adventitious Root Formation, CR - Cellose Roots; NR - No Response, NA- Not Applicable, Mean \pm SD*: Twenty replicates/treatment

All the soil samples collected from In Delicious apple cultivars rooting percentage and the number of roots in microshoots increased with increase in the number of subcultures (Sriskandrajah et al., 1982). The P studies have also shown similar pattern of rooting response.

\section{Hardening of the microplants}

The microplants produced through shoot tip culture were taken out of culture vials very 
carefully, roots were washed under running water to remove agar and then they were transferred to pots containing soil mix (soil - peat 1:1). Potted plants were covered by perforated polyethene bags and kept under continuous observation. The plants were misted after regular intervals to maintain maximum humidity (90-100\%) under laboratory conditions (Plate-A, Fig. 3; B, Fig. 6; C, Fig. 6). The survival rate was found to be $80 \%$ in the plants obtained through MTEC and $95 \%$ in those obtained through SBEC.

\section{Establishment of Protocol for micro plant production}

From aforementioned observations it can be envisaged that the establishment of the explants from mature trees (MTEs) and seedling born explants (SBEs) of Galmast cultivar occurs best on $\mathrm{MS}\left(\times^{1 / 2}\right)+\mathrm{BA}(4.0$ $5.0 \mu \mathrm{M})+\mathrm{PG}(10 \mu \mathrm{M})$, shoot multiplication occurs best on same medium augmented with $\mathrm{BA}(4.0 \mu \mathrm{M})+\mathrm{PG}(10 \mu \mathrm{M})$ and root induction occurs best on the medium containing $\operatorname{IBA}(2.5 \mu \mathrm{M})+\mathrm{PG}(10 \mu \mathrm{M})$. An outline of the complete protocol of shoot tip culture of Galmast cultivar of apple obtained from mature trees has been summarised in Plate-A for its clonal propagation.

\section{References}

Bahmani R., Gholami M., Abdollahi H and Karami O (2016). The Effect of Carbon Source and Concentration on In Vitro Shoot Proliferation of MM.106 Apple Rootstock.pp 35-37

Ciccotti AM., Bisognin C., Battocletti I., Salvadori A., Herdemertens $\mathrm{M}$ and Jarausch W (2008). Micropropagation of apple proliferation-resistant apomictic Malussieboldii genotypes.Agronomy Research. 6(2): 445-458.

Dobranski J., Hudak I., Tabori K., Benczur EJ., Galli Z and Kiss E (2002). How Can
Different Cytokinins Influence The Process of Shoot Regeneration From Apple Leaves in 'ROYAL GALA' and 'M.26'. ActaHorticulturae. 725:191-196

Dobránszki J, Teixeira da Silva JA (2010). Micropropagation of apple- a review.Biotechnol Adv. 28:462-488.

Dobránszki J., Mendler-Drienyovszki N (2015).Cytokinins and photo- synthetic apparatus of leaves on in $\neg$ vitro axillary shoots of apple cv. Freedom. Hungarian Agric Res. 1:20-24

GamborgOL., Miller RA., Ojima K (1968). Nutrient requirements of suspension cultures of soybean root cells. Exp Cell Res. 50:151-158.

Gladyshava LA (1987). Production and morphogenesis of apple tissue. Stuinca. 23:138-144 (USSR).

Hammatt N, \& Grant NJ (1993). Apparent rejuvenation of mature wild cherry (Prunusavium L.) during micropropagation. J. Plant Physiol. 141; 341-346.

James DJ and Thurbon IJ (1981). Phenolic compunds controlling rhizogenesis in vitro in the apple root stocks M.9 and M.26. Z. Pflanzen Physiol. 105: 1-10.

Kouider M., Korban S., Skirvin MR. and Chu MC (1984b). Influence of embryonic dominance and polarity on adventitious shoot formation from apple cotyledons in vitro. Journal of American Society of Horticultural Science. 109(3): 381-385.

Laimer M., Barba M (2011). Elimination of systemic pathogens by ther- motherapy, tissue culture, or in 7 vitromicrografting. In: Hadidi A, Barba M, CandresseTh, Jelkmann W (eds) Virus and Virus-like Diseases of Pome and Stone Fruits. APS, St. Paul, pp 389-393

Lloyd G., McCown B (1980). Commerciallyfeasible micropropagation of mountain laurel, Kalmia latifolia, by use of shoottip culture. Intl Plant Propagators' Soc Proc. 30:421-427

Modgil M., Sharma DR., Bhardawaj SV and Khosla K (1994). In vitro propagation of apple (MalusdomesticaBorkh) Cv. 
Golden Delicious.Indian Journal of Horticulture. 51(2): 111-118

Modgil M., Sharma DR., Bhardawaj SV and Khosla K (1994).In vitro propagation of apple (MalusdomesticaBorkh) Cv. Golden Delicious.Indian Journal of Horticulture. 51(2): 111-118

Murashige T and Skoog, F (1962) PHYSIOL.Planta. 15;473-497

Nabeela BA., Darkazanli K and Kader AMA (2009). (Syria) Direct Organogenesis and Plantlet Multiplication from Leaf Explants of in Vitro-Grown Shoots of Apple (MalusdomesticaBorkh.) cv. 'Golden Delicious' and MM111.Rootstock Fruit, Vegetable and Cereal Science and Biotechnology. 3(1): 28-34.

Pawlicki N and Welender M (1992). The effect of benzyl adenine and gibberellic acid on adventitious root formation in apple stem discs. Agronomic. 12(10): 783-88.

Puente J and Marin JA (1992). Splitting of Malusmicrocuttings enhances rooting. Agronomie. 12(10): 795-797.

Quoirin M., Lapoivre $\mathrm{P}$ and Boxus $\mathrm{P}$ (1977).Un premier bilan de 10 annees de recherchessur les cultures de meristeme at la multiplication in vitro de fruitiersligneux. In: C. R. Rech 1976-77 et Rapports de Synthese, Stat. Cult. Fruit. Et Maraich. Gembloux.pp 93-117.

Quoirin M., Lepoivre P (1977). Improved media for in $\neg$ vitro culture of Prunus sp. ActaHortic. 78:437-442.

Rom RC., Carlson RF (1987). Rootstocks for Fruit Crops. Wiley, New York, p 494

Sharma RK.,Barna KS and Wakhlu AK (2004). Effect of Thidiazuron on micropropagation of Maluspumila Mill.
Cv. Ambri. Oriental Science. 9:31-36.

Sriskandarajah S., Mullins MG and Nair Y (1982). Induction of adventitious rooting in difficult to propagate cultivate of apple. Plant Science letters. 24: 1-9.

Teixeira da Silva JA (2012a). BA (6benzyladenine) BAP (6-benzylaminopurine)?Asian Aust J Plant SciBiotechnol. 6:121-124

Teixeira da Silva JA (2012b). Callus, calluses or calli: multiple plurals? Asian Aust J Plant SciBiotechnol. 6:125-126

Teixeira da Silva JA.,Dobránszki J (2011). The plant Growth Correction Factor. I. The hypothetical and philosophical basis. Intl J Plant Dev Biol. 5:73-74

Teixeira da Silva JA.,Dobránszki J (2014). Dissecting the concept of the thin cell layer: theoretical basis and practical application of the plant growth correction factor to apple, Cymbidium and chrysanthemum. J Plant Growth Reg. 33:881-895

Welander M (1988). Plant regeneration from leaf and stem segments of shoots raised in vitro from mature apple trees. Journal of Plant Physiology. 132: 738-744.

White PR (1943). A Hand Book Tissue Culture. Ronald Press. New York.

Zimmerman R H. and Fordham I (1989).Simplified method for rooting apple cultivars in vitro.Journal of American Society of Horticultural Science. 110(1): 34-38.

Zimmerman RH (1981). Micropropagation of fruit plants. Acta Hort. 120; 217-222.

Zimmerman $\mathrm{RH}$ and Broome OC (1981).Phloroglucinol and in vitro rooting of apple cuttings.Journal of American Society of Horticultural Science. 106: 648-652

\section{How to cite this article:}

Subzar Ahmad Rather and Junaid Jalal. 2019. In-vitro Regeneration of Apple Cultivar (Malus domestica L. cv. Galmast). Int.J.Curr.Microbiol.App.Sci. 8(10): 2606-2622.

doi: https://doi.org/10.20546/ijcmas.2019.810.301 